\title{
Developmental Neuroscience
}

Founded 1978 by A. Vernadakis and E. Giacobini

Continued by N. Baumann (1983-1992); A.T. Campagnoni (1987-2008);

S.W. Levison (2009-2019)

\section{Editor-in-Chief}

Joseph LoTurco - University of Connecticut, Storrs, CT, USA

\section{Associate Editors}

Pradeep G. Bhide - Florida State University, Tallahassee, FL, USA Jean M. Lauder - University of North Carolina, Chapel Hill, NC, USA Carina Mallard - Gothenburg University, Gothenburg, Sweden Richard S. Nowakowski - Florida State University, Tallahassee, FL, USA Debra L. Silver - Duke Institute for Brain Sciences, Durham, NC, USA Gregg D. Stanwood - Florida State University, Tallahassee, FL, USA Francis Szele - University of Oxford, Oxford, UK Sidhartha Tan - Wayne State University, Detroit, MI, USA

\section{Editorial Board}

Klas Blomgren - Karolinska University Hospital, Stockholm, Sweden Russell W. Brown - East Tennessee State University, Johnson City, TN, USA Anthony T. Campagnoni - UCLA Semel Institute for Neuroscience, Los Angeles, CA, USA Daniel B. Campbell - Michigan State University, Grand Rapids, MI, USA Kenneth Campbell - University of Cincinnati, Cincinnati, OH, USA Josh Corbin - Children's National Medical Center, Washington, DC, USA Richard H. Dyck - The University of Calgary, Calgary, AB, Canada Amelia J. Eisch - University of Pennsylvania, Philadelphia, PA, USA Michael A. Fox - Virginia Tech Carilion Research Institute, Roanoke, VA, USA James E. Goldman - Columbia University, New York, NY, USA Mohammad Hajihosseini - University of East Anglia, Norwich, UK Corey Harwell - University of California at San Francisco, San Francisco, CA, USA Tarik F. Haydar - Boston University, Boston, MA, USA Soumya lyengar - National Brain Research Centre, Gurgaon, India Barry E. Kosofsky - Weill-Cornell Medical College, New York, NY, USA Anthony LaMantia - Fralin Biomedical Research Institute at VTC, Roanoke, USA Steven W. Levison - NJMS-UH Cancer Center, Newark, NJ, USA Mary C. MCKenna - University of Maryland, Baltimore, MD, USA Patrick McQuillen - University of California, San Francisco, CA, USA Klaus-Armin Nave - Max-Planck-Institute for Experimental Medicine, Göttingen, Germany Akiko Nishiyama - University of Connecticut, Storrs, CT, USA Linda J. Noble - University of Texas at Austin, Austin, TX, USA 


\section{Developmental}

\section{Neuroscience}

(Continued)

Andre Obenaus - University of California, Irvine, CA, USA

Juana M. Pasquini - University of Buenos Aires - CONICET, Buenos Aires, Argentina

J.Regino Perez-Polo - Shriner's Hospital for Children, Galveston, TX, USA

Donald W. Pfaff - The Rockefeller University, New York, NY, USA

Samuel J. Pleasure - UCSF Institute for Regeneration Medicine, San Francisco, CA, USA

Ramesh Ragupathi - Drexel University, Philadelphia, PA, USA

João B. Relvas - Universidade do Porto, Porto, Portugal

Courtney L. Robertson - University of Maryland, Baltimore, MD, USA

Beth Stevens - Boston Children's Hospital, Boston, MA, USA

Shubha Tole - Tata Institute of Fundamental Research, Mumbai, India

Flora M. Vaccarino - Yale University, New Haven, CT, USA

Susan J. Vannucci - Weill Cornell Medical College, New York, NY, USA

David W. Walker - RMIT University School of Health and Biomedical Sciences, Melbourne, VIC, Australia

Zhengang Yang - Fudan University, Shanghai, China

Bernard Zalc - Hôpital de la Salpêtrière, Paris, France

Changlian Zhu - Zhengzhou University, Zhengzhou, China 
S. Karger

Medical and Scientific Publishers
Disclaimer

The statements, opinions and data contained in this publication are solely those of the individual authors and contributors and not of the publisher and the editor(s). The appearance of advertisements in the journal is not a warranty, endorsement or approval of the products or services advertised or of their effectiveness, quality or safety. The publisher and the editor(s) disclaim responsibility for any injury to persons or property resulting from any ideas, methods, instructions or products referred to in the content or advertisements.

Drug Dosage

The authors and the publisher have exerted every effort to ensure that drug selection and dosage set forth in this text are in accord with current recommendations and practice at the time of publication. However, in view of ongoing research, changes in government regulations, and the constant flow of informain government regulations, and the constant flow of informa-
tion relating to drug therapy and drug reactions, the reader is urged to check the package insert for each drug for any change in indications and dosage and for added warnings and precautions. This is particularly important when the recommended agent is a new and/or infrequently employed drug.
All rights reserved.

No part of this publication may be translated into other languages, reproduced or utilized in any form or by any means, electronic or mechanical, including photocopying, recording, microcopying, or by any information storage and retrieval system, without permission in writing from the publisher or, in the case of photocopying, direct payment of a specified fee to the Copyright Clearance Center (see "General Information").

(c) Copyright 2021 by S. Karger AG

CH-4009 Basel (Switzerland)

Printed on acid-free and non-aging paper (ISO 9706) karger@karger.com

www.karger.com 
No. 1

Review Article

1 Left Hemisphere Lateralization of Epileptic Focus Can Be More Frequent in Temporal Lobe Epilepsy Surgical Patients with No Consensus Associated with Depression Lateralization Radaelli, G. (Porto Alegre); Majolo, F. (Porto Alegre/Lajeado);

Leal-Conceição, E.; de Souza Santos, F.; Escobar, V.; Zanirati, G.G.;

Portuguez, M.W. (Porto Alegre); Scorza, F.A. (São Paulo/Porto Alegre); da Costa, J.C. (Porto Alegre)

Research Articles

9 Long Noncoding RNA SPRY4-IT1 Modulates Ketamine-Induced Neurotoxicity in Human Embryonic Stem Cell-Derived Neurons through EZH2

Huang, J.; Xu, Y.; Wang, F.; Wang, H.; Li, L.; Deng, Y.; Cai, L. (Xi'an)

18 Neonatal Rats Exhibit a Predominantly Anti-Inflammatory Response following Spinal Cord Injury

Sutherland, T.C.; Ricafrente, A.; Gomola, K.; O’Brien, B.A.; Gorrie, C.A. (Sydney, NSW)

27 Developing Brain Glucose Transporters, Serotonin, Serotonin Transporter, and Oxytocin Receptor Expression in Response to Early-Life Hypocaloric and Hypercaloric Dietary, and Air Pollutant Exposures

Ye, X.; Shin, B.-C.; Baldauf, C.; Ganguly, A.; Ghosh, S.; Devaskar, S.U. (Los Angeles, CA)

43 Expression Analyses of Mediator Complex Subunit 13-Like: A Responsible Gene for Neurodevelopmental Disorders during Mouse Brain Development

Hamada, N.; Iwamoto, I.; Nishikawa, M. (Kasugai); Nagata, K. (Kasugai/ Nagoya)

53 Aluminum Microcomb Electrodes on Silicon Wafer for Detecting Val66Met Polymorphism in Brain-Derived Neurotrophic Factor

Li, Z.; Cui, L.; Zhao, H.; Du, J. (Jinan); Gopinath, S.C.B. (Arau/Kangar); Lakshmipriya, T. (Kangar); Xin, X. (Jinan)

63 Repetitive Mild Traumatic Brain Injury in a Perinatal Nicotine Exposure Mouse Model of Attention Deficit Hyperactivity Disorder

Zhang, L.; Levenson, C.W.; Salazar, V.C.; McCarthy, D.M. (Tallahassee, FL), Biederman, J. (Boston, MA); Zafonte, R. (Charlestown, MA); Bhide, P.G. (Tallahassee, FL)
No. 2

Review Article

73 The Dopamine Hypothesis of Autism Spectrum Disorder Revisited: Current Status and Future Prospects Pavăl, D.; Micluția, I.V. (Cluj-Napoca)

Research Articles

84 Zebrafish Minichromosome Maintenance Protein 5 Gene Regulates the Development and Migration of Facial Motor Neurons via Fibroblast Growth Factor Signaling Wu, Y.; Huang, S.; Zhao, H.; Cao, K.; Gan, J.; Yang, C.; Xu, Z.; Li, S.; Su, B. (Chengdu)

95 Adverse Maternal Environment Alters MicroRNA-10b-5p Expression and Its Epigenetic Profile Concurrently with Impaired Hippocampal Neurogenesis in Male Mouse Hippocampus

Ke, X. (Kansas City, MO); Huang, Y. (Haikou); Fu, Q.; Lane, R.H. (Kansas City, MO); Majnik, A. (Milwaukee, WI)

106 Maternal Interleukin-6 Hampers Hippocampal Neurogenesis in Adult Rat Offspring in a Sex-Dependent Manner Mouihate, A.; Kalakh, S. (Safat)

116 Identifying Dyslexia: Link between Maze Learning and Dyslexia Susceptibility Gene, DCDC2, in Young Children Gabel, L.A.; Voss, K. (Easton, PA); Johnson, E. (Boise, ID); Lindström, E.R. (Bethlehem, PA); Truong, D.T. (New Haven, CT); Murray, E.M.; Cariño, K. (Easton, PA); Nielsen, C.M. (Bethlehem, PA); Paniagua, S.; Gruen, J.R. (New Haven, CT)

Commentary

134 Enhancing Translational Developmental Cognitive Neuroscience with Advanced Neuroimaging Analyses Levine, S.M. (Mannheim)

\section{No. 3-4}

Targeted Therapies for Neurodevelopmental Disorders Guest Editors: Goldberg E.M. (Philadelphia, PA); Tzingounis A.V. (Storrs, CT)

Editorial

141 Towards Targeted Therapy for Neurodevelopmental Disorders Symposium

Goldberg, E.M. (Philadelphia, PA); Tzingounis, A.V. (Storrs, CT) karger@karger.com

www.karger.com

Karger $\stackrel{\text { ' }}{=}$
(C) 2021 S. Karger AG, Basel

Access to full text and tables of contents, including tentative ones for forthcoming issues: www.karger.com/dne_issues 
Models and Mechanisms: Reviews

143 Current Approaches and Future Directions for the Treatment of mTORopathies

Karalis, V. (Berkeley, CA); Bateup, H.S. (Berkeley, CA/San Francisco, CA)

159 Molecular and Cellular Function of Transcription Factor 4 in Pitt-Hopkins Syndrome

Chen, H.-Y.; Bohlen, J.F.; Maher, B.J. (Baltimore, MD)

168 A Role for Vasoactive Intestinal Peptide Interneurons in Neurodevelopmental Disorders

Goff, K.M.; Goldberg, E.M. (Philadelphia, PA)

181 Abnormal Cerebellar Development in Autism Spectrum Disorders

van der Heijden, M.E.; Gill, J.S.; Sillitoe, R.V. (Houston, TX)

191 Flexible Stoichiometry: Implications for KCNQ2- and KCNQ3Associated Neurodevelopmental Disorders

Springer, K.; Varghese, N.; Tzingounis, A.V. (Storrs, CT)

201 Dendritic Integration Dysfunction in Neurodevelopmental Disorders

Nelson, A.D.; Bender, K.J. (San Francisco, CA)

Models and Mechanisms: Mini Review

222 Mitochondrial Dysfunction: A Common Denominator in Neurodevelopmental Disorders?

Ortiz-González, X.R. (Philadelphia, PA)

Therapeutic Strategies: Review

230 Gene Transfer Therapy for Neurodevelopmental Disorders Ozlu, C.; Bailey, R.M.; Sinnett, S.; Goodspeed, K.D. (Dallas, TX)

Therapeutic Strategies: Mini Reviews

241 Targeting Poison Exons to Treat Developmental and Epileptic Encephalopathy

Aziz, M.C. (Chicago, IL); Schneider, P.N. (Chicago, IL/Belem); Carvill, G.L. (Chicago, IL)

247 Antisense Oligonucleotide Therapy for Neurodevelopmental Disorders

Hill, S.F.; Meisler, M.H. (Ann Arbor, MI)

253 CRISPR/dCas9 as a Therapeutic Approach for Neurodevelopmental Disorders: Innovations and Limitations Compared to Traditional Strategies

Ricci, R.; Colasante, G. (Milan)

262 Author Index/Subject Index

No. 5

Review Articles

263 The Role of Hippo Signaling Pathway in the Development of the Nervous System

Li, X.; Li, K.; Chen, Y.; Fang, F. (Guilin)

271 Effects of Prenatal Methamphetamine Exposure on Birth Outcomes, Brain Structure, and Neurodevelopmental Outcomes

Zhang, Y.; Gong, F.; Liu, P.; He, Y.; Wang, H. (Xiłan)
Research Articles

281 Insulin-Like Growth Factor 1 in the Preterm Rabbit Pup: Characterization of Cerebrovascular Maturation following Administration of Recombinant Human Insulin-Like Growth Factor 1/Insulin-Like Growth Factor 1-Binding Protein 3 Gram, M.; Ekström, C.; Holmqvist, B. (Lund); Carey, G. (Boston, MA); Wang, X. (Gothenburg); Vallius, S. (Lund); Hellström, W. (Gothenburg); Ortenlöf, N.; Agyemang, A.A. (Lund); Smith, L.E.H. (Boston, MA); Hellström, A. (Gothenburg); Mangili, A. (Zurich); Barton, N. (Boston, MA); Ley, D. (Lund)

296 Galectin-3 Modulates Microglia Inflammation in vitro but Not Neonatal Brain Injury in vivo under Inflammatory Conditions Sävman, K.; Wang, W.; Rafati, A.H.; Svedin, P.; Nair, S.; Golubinskaya, V.; Ardalan, M. (Gothenburg); Brown, K.L. (Vancouver, BC); Karlsson-Bengtsson, A.; Mallard, C. (Gothenburg)

312 Febrile Seizure-Related miR-148a-3p Exerts Neuroprotection by Promoting the Proliferation of Hippocampal Neurons in Children with Temporal Lobe Epilepsy

Yu, Y.; Du, L.; Zhang, J. (Liaocheng)

No. 6

Research Articles

321 Mapping Angiopoietin1 Expression in the Developing and Adult Brain

Wei, X. (Cincinnati, OH); Jessa, S.; Kleinman, C.L. (Montreal, QC); Phoenix, T.N. (Cincinnati, $\mathrm{OH}$ )

335 Pediatric Moderate-Severe Traumatic Brain Injury and Gray Matter Structural Covariance Networks: A Preliminary Longitudinal Investigation

Tuerk, C.; Dégeilh, F. (Montreal, QC); Catroppa, C.; Anderson, V. (Melbourne, VIC); Beauchamp, M.H. (Montreal, QC)

348 Nonsyndromic Early-Onset Epileptic Encephalopathies: Two Novel KCTD7 Pathogenic Variants and a Literature Review Binaafar, S.; Garshasbi, M.; Tavasoli, A.R.; Badv, R.S.; Hosseiny, S.M.M. (Tehran); Samanta, D. (Little Rock, AR); Rabbani, B.; Mahdieh, N. (Tehran)

358 Prenatal Exposure to Tobacco and Alcohol Alters Development of the Neonatal Auditory System Sininger, Y.S. (Los Angeles, CA/Santa Fe, NM); Condon, C.G.; Gimenez, L.A.; Shuffrey, L.C.; Myers, M.M. (New York, NY); Elliott, A.J. (Sioux Falls, SD); Thai, T.; Nugent, J.D.; Pini, N.; Sania, A. (New York, NY); Odendaal, H.J. (Cape Town); Angal, J.; Tobacco, D. (Sioux Falls, SD); Hoffman, H.J. (Bethesda, MD); Simmons, D.D. (Waco, TX); Fifer, W.P. (New York, NY)

Brief Report

376 Cocaine Elevates Calcium-Dependent Activator Protein for Secretion 2 in the Mouse Orbitofrontal Cortex Trinoskey-Rice, G.E.; Woon, E.P.; Pitts, E.G.; Gourley, S.L. (Atlanta, GA)

383 Acknowledgement to Reviewers 